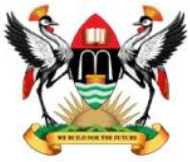

East African School of Higher Education Studies \& Development
Makerere Journal of Higher Education

ISSN: 1816-6822; 7 (2) (2015) $61-69$

DOI: http://dx.doi.org/10.4314/majohe.v7i2.4

(C) The Author(s) 2015

Reprints \& permission: EASHESD

http://ajol.info/majohe

\title{
Changing Needs of Business Education Students with Specific Reference to Secretarial Studies
}

\author{
Amina Sani ${ }^{1}$ \\ ${ }^{1}$ Department of Business Education, Federal College of Education, Zaria [E-mail: \\ aminailo@yahoo.com]
}

\begin{abstract}
The need to face emerging challenges squarely should not be disregarded in today's world. Higher education is at the centre of preparing future business professionals and equipping them with the knowledge, skills and attitudes they will need address the emerging challenges of this century. Making specific reference to the Secretarial Component of Business Education, this paper demonstrates that contemporary needs are changing rapidly. Therefore, the paper argues, education and training should change. Recommendations towards achieving these suggestions are made.
\end{abstract}

Keywords: Business education; Secretarial studies; Educational reform

\section{$1 \quad$ Introduction}

To live and survive satisfactory entails a challenge. Experts connote this to mean survival of the fittest. The struggle for relevance continues from one generation within a century to another. The secretary is not left behind in the quest for relevance and survival in his chosen career. It is this clarion call for existence that stimulate him to learn, to struggle and to professionalize.

Challenges ranging from simple telephone handling, to computer literacy as well as internet browsing calls for relevant educational training. The world is ever progressing. What is relevant yesterday could not be so today and so will when it reaches tomorrow.

Social scientists posit that there is nothing permanent except change. So it is the duty of today's secretary to equally ascribe to the challenges being posed by the changing circumstances of today in order to be relevant tomorrow. It is a known fact that a secondary school leaver with the simple skill of typewriting and knowledge of office practice could be employed as an office secretary in 
the 60s. Later, challenges brought about the need for shorthand, secretarial duties, and English language along the line. In the early 70s, such things like electric typewriter, telephone handling, conference meeting arrangement, reprographic work, petty imprest handling were evolved to further invigorate and professionalize the career.

Here we are today; in the era of complex and sophisticated office automation that could better be seen than being imagined. The secretary is here as a copartner to the puzzle. Adebayo (2002) referred to education as systematic instruction, development of character or mental powers. The national policy on education (1989) referred to it as a dynamic instrument of change.

It is view of Agomu (2002) that training provides skills, knowledge and attitudes necessary to undertake required job efficiently. In the words of Aliyu (2001) the word 'need' implies that something is lacking while 'training' implies that lack can be supplied by systematic training. He concluded that training need exists when the application of systematic training will serve to overcome a particular weakness.

The word secretary, according to Aliyu (2001) is derived from a Latin word seretarus meaning 'something known only to one of few and kept secret or hidden from the view and knowledge of others'. This means, a secretary is a keeper of secrets.

The justification of training needs is the first in the educational process. Just like in every systematic process; its success or failure will correspondingly affect subsequent educational developmental stages. The secretary needs to undergo educational training in the following areas in order to meet up with today's challenges in the world of work; information and communication technology, office skills, computer and word processing, internet, public relation, management and administrative skills, machine technological skills etc.

Having recognized the need for keeping secretaries up-to-date on the latest educational developments in office technology, several business educators and industrial leaders have dramatically put this in perspective as a result of the decline in value of secretarial personnel, Ibigbami (2001) posited that unless a secretary of $n$ ten years ago spend ten percent $t$ of his time developing his knowledge beyond the level of his collegiate training, he cannot compete in value with the new graduates. The analysis further assumes that the secretary retains all his previous training.

He also asserted that if an estimate of decay from neglect or disguise is also ten percent per year, a secretary is faced with task of growing in new knowledge at the rate of about twenty percent per years to remain of equal value to his employer and society, hence the urgent need in retraining in education, he deduced. 
Ibigbami (2001) opined that 'if education is to take new and dynamic significance, it must be aimed at training the child for some specific skills' so as to fit in to the age of industrial era that requires youths to be exposed to varieties of skills and competencies. This is more so as the modern office is becoming a rapidly changing place while it demands are also becoming diversified in this age office automation.

Ibigbami (2001) remarked.' enterprises and organizations have grown in size as technology has created a new kind of world. Industry and the office have been computerized and managed scientifically. Office work has become specialized, sub-divided and standardized and it is now composed of repetitive operations interchangeable activities and non-discretionary assignments.

The challenges then to teachers in preparing secretarial students/workers for entry in to modern offices are to stress the educational development desirable for work habit and attitude as well as high operative skills. While contributing on the relevance and educational challenges ahead of the practicing secretary, Otoba (2002) posited that secretary is very relevant in the business world. There is no gainsaying that he is an indispensable figure in every aspect of an organization.

Faced with current managerial challenges and responsibilities, he may not be adequately prepared with his current educational training in the Nigeria setting for him to cope with the changes and challenges going on in today's office. The use of relevant curriculum with the appropriate modern tools and equipment to face the challenges has become a paramount topic for discussion by all those in charge of education

Several writers have commented on the current state of secretarial educational training, stressing the need for change. Otoba (2002) stated that the work of the professional secretary as change from the traditional office routine of handling mails manually to the application of modern office techniques and the use of sophisticated office equipment in the processing of information. Otoba (2002) elaborated more specifically on the functions of today's secretary by saying that, today the secretary can be expected to create text and tables of figures, edit, file, retrieve, calculate and (electronically) all with same office system and probably more.

Agomuo (2002) pointed out that the role of secretaries in modern offices has begun to splinter. They now include:

1. The word processing secretary who keyboards.

2. Correspondence and other business papers.

3. The correspondence secretary who originate.

4. The secretary who issue out materials.

5. The financial secretary using microcomputers. Handles payments and petty cash funds. 
6. The data processing secretary who handles inventory of office equipment and attendant repair services and contract.

It, therefore, becomes clear from the view of Agomuo (2002) that advice in office technology (from the shole's first typewriter in 1868to the word processor in 1964), new procedures which have evolved from the traditional office systems and operations in to the ever -widening horizons of modern information technologies and the concept of work specialization, have added new dimensions to the role of the secretary.

Agomuo (2002) stated that the modern business office has gone through great metamorphosis, and that automation and the changes it brought to the business office are greatly altering the skills required by employers.

Idih (1998) in Agomuo (2002) noted that Nigeria is fast moving in to the 21 century with its constantly changing technology .youths would be able to face the challenges of the electronics era and the future demands of employers are highly needed.

\section{Contemporary Challenges Facing Business Education Students}

Knowing fully well that the educational quest of the secretary cannot be met in the solitary, hence it must be conjoined with other institutional-cum-personality stakeholder associated with imparting, financial, utilizing and perfecting the theory and practice of knowledge. These educational stakeholders include among other things.

1. The student himself.

2. The secretarial teacher.

3. The institution providing knowledge.

4. The utilizers of knowledge-employers

5. The financier of the knowledge -industry i.e. Government etc.

They will be looked in to extensively with the view to finding out the extent of their preparation for the tasks ahead.

\subsection{The Secretary}

In the past, the need for modern office machines and equipment did not arise. this was mainly because, the secretaries than could make do with the manual typewriters, manually operated photocopying and duplicating machines and other office equipment operated manually to do their work irrespective of the length of time and energy they exert. The in accuracies, inefficiencies and nonstandardization it on the manual typewriter, they would be satisfied that they 
have done their work. But now, the role of the secretary in today's office has risen beyond that role. According to Oguoma (2002), secretary possesses mastery of skills and ability to assume responsibility; he displays initiative, exercises judgment and makes decision in today's office. The secretarial profession has become vast and highly demanding than it used to be in the past, hence, the need to change from the use of archaic and slow manual office equipment and machines to highly sophisticated ones This will enable them to imbibe modern office automation.as new business and job opportunities are generated every day, there comes a need for secretaries to match the challenges by acquiring new skills and competencies for the operation of those new technologies. Secretaries who are not well equipped in terms of new skills and competencies, knowledge and abilities for today and tomorrow's office are sure to be embarrassed as their inadequate skills will render them redundant or even thrown out of job, hence consulting a challenge to their educational attainment and aptitude.

\subsection{The Secretarial Teacher}

Adebayo (2002) asserted that qualities are substance that cannot be seen nor touched, but rather are bunch of attributes that are required as an ingredient to furnish a professional teacher's enroot the actualization of his schedule duties. Hence forth, he is expected to acquire such charismatic and charming intrinsic/ extrinsic elements that would enable him to practice efficiently the ethics of his chosen $\mathrm{m}$ profession he is expected to have sound reason in whatever things he does. He should be fluent in speech, logical in thought, systematic in deed and articulate in approach to things. The secretarial teacher should always be optimistic, forward looking and making the most out of unfavourable and unfortunate situations. The teacher as certain role to play for the educational and national development of Nigeria. As Aliyu (2001) posted, he should develop an industrial plan serve as a resource person for students, analyse their performance, counsel them and motivate them toward effective tasks performance.as an educational consult, he should help to formulate relevant statement of philosophy and objectives in business, help plan, evaluate and modify curriculum content to reflect on changing and challenging trends on education like the one we are in now. The educational attainment of the teacher also is concern for the secretarial student. That he should be professionally trained to the core could never be said to be too much.to this end, the secretarial teacher should endeavour to keep attuned to further training and retraining by possessing the minimum qualification of NCE(business), or bachelors, master degree or even Ph.D. as the case might be. To buttress further on the quest for quality in teaching as a pivot for quality education and national development, the national policy on education (1989), section 9, sub-section 57 through 59 
have this to say: teacher education will continue to be given a major emphasis in all our educational planning because no education system can rise above the quality of its teachers. Also that the purpose of teacher education should be:

1. To produce highly motivated, conscientious and efficient classroom teachers for all levels of our education systems.

2. To encourage further the spirit of enquiry and creativity in teachers:

3. To help teachers to fit in to the social life of the community and society at large and enhance their commitment to national objectives.

4. To provide teachers with the intellectual and professional background adequate for their assignment and to make them adaptable to any changing situation not only in the life of their country, but in the wider world.

5. To enhance teacher's commitment to our educational institutions, from per - primary to university, will be professionally trained. Teacher education programmes will be structured to equip theme for the effective performance of their duties.

\subsection{The Institutional Setting}

The curriculum of secretarial studies as formulated by the national board for technical education (NBTE) had the objective of producing the type of man power required by the nation at the secretarial level. The curriculum as it applies to the various programme of secretarial studies seem to be comprehensive when evaluated on their individual merits, but something seems to be lacking, Oguoma (2002) asserted that this is the inability of the formulators (NBTE) and the implementers (higher institutions) to periodically review the content in line with environmental changes that tend to affect the work place where the recipients of this education are expected to function.

He further posited that result has been that lack of adequate and proper link between industry requirement (attitude skill and knowledge) on the part of graduates and means of inculcation while in the school.

This is more of a national problem since graduates of secretarial studies tend to find it difficult competing with others for the limited employment opportunities available.at the same time, employers tend to believe they spend money retraining secretarial graduates on skill, knowledge and attitude required when employed. Aminu, (2006), stated that the secretarial studies designed curriculum only emphasized the acquisition of such traditional skills of shorthand writing, effectively typewriting on manual /electric typewriters, and arrangement of meetings, file management, information storage and provision. those required skills however, tends to lack touch with the realities of pract6ical industrial practice of the profession, since it seems to lose sight of the innovation of information technology as made possible by the merger between 
computers and satellite system via wave signals and its effect on the modern work environment, Oguoma added.

The secretary has the mandate for the managing of information system as it relate to the organisation. He added that, information management, has become complex given the increasing volume of information that came in and the increasing demand by user of such information. These implies that storage; processing and retrievals of it are becoming a challenge to secretaries. Technological innovation has change the face of the industrial activities and that trainer of prospective secretaries must be mindful of it in other to produce graduate who have the skill. Knowledge and the attitude to face the challenges of the industrials system that is information technology driven.

\subsection{The Employers}

The needs to overhaul business education programme to accommodate the modernization trend in the job market remains a big challenge to the stakeholders in the education for job seeking and job creation. In the opinion of Nwosu (1999) in Oyeduso (2003), since curriculum should be adaptive and relevant, developers of curriculum in office education or in any of the business areas have a responsibility to monitor technological advancements in office and constantly re-viewing the curriculum to meet the demands of the office.

Selden (1981) and Nwosu (1999) in Ayeduso (2003) opined that occupational preparation must be redesigned to stimulate the working environments that are actually found in the offices. They believe that, for the student to prepare for the world of work, the needs and desired of employers of labour be incorporated in to the curriculum and the trainers must possess the skills they develop.

All hands must therefore be on deck by all that are involved in provision of education for students desiring careers in business and/or for developing consumer and economic understanding and competencies.

The demand of employers of labour have completely from what it was a decade ago. The change has become imperative as a result of monumental improvement in technology that is the integrations of the computer with sophisticated communication system, which revolutionize business activities in industries and the world of work generally

Ayeduso (2003) pointed out that the world is characterised by fraudulent business practices.so those to work in it should be trained specially to be able to demonstrate a high level of business ethics, honesty, transparency, trustworthiness, etc. Business education curriculum should be designed in such a way that these could be made possible. 


\subsection{The Government}

On the administration and planning of education NPE (1989) section 11 subsection 85 through 86 had it that: The success of any system of education is hinged on proper efficient administration and adequate financing also that, school system and consequently their management and day to day administration should grow out of the life and social ethos of the community which they serve. Knowing fully well that nothing can go down well without financial where withal section 12 sub-section 105 through 107 had it that: Education is an expensive social service and requires adequate financial provision from all tiers of government. The ultimate objective is to make education at all level jointly financed by three tiers of government vis-à-vis the participation of local communities, individuals and other organisation. Equally, government recognised the importance of technical and commercial education with the needs to relate its programme to requirements of commerce and industry.

\section{Recommendations}

Secretaries should realized the need for them to keep abreast with the modern information technology challenges and subscribe to acquiring educational training in order to remain relevant. Teachers should always endeavour to possess the highest educational and professionals qualification relevant to their specification as well as to browse the technological innovation of modernity for them to be relevant. The curriculum regulating body should in earnest constitute a committee of experts to review its contents in line with the twentyfirst century education-cum business challenges in technology higher institution of learning should--as a matter of urgency attempt to inculcate the right skills, knowledge and attitude required of the wider business-cum-labour market. They should equally be able to produce and stock their pools with the relevant modern information equipment to facilitate this and related processes. The government should live up to its policy statement in planning and administration of quality education in particular and education institutions in general across the nation. In the same vein, government should, as a matter of necessity release funds sufficient enough to cater for all demands relating to the educational sub-sector across the nation. Communities, individuals and corporate organisations should complement government efforts in financing education to boost national development in consonance with the development world. Henceforth, employers should not relent in their effort to complement government's role by retraining graduates to suit information technology 
requirement. They should, as a matter of nationalism, set a separate fund to further invigorate educational training and development.

\section{References}

Adebayo, (2002). Principle and practice of education (Revised Edition).Ado Ekiti: Omalayo Standard Press and Bookshops (Nig) Ltd, pp. 80-82.

Agomu, O. E., Christy O. Isu (2002).Secretary Job-Tasks. Required in modern Business offices in Abia State implications for improved secretarial Education. Business Education Journal. 3 (5), p.6.

Aliyu, M.M (2001).Business Education in Nigeria (Trend and Issues). Zaria: ABU Press Ltd.

Ayeduso, O. (2003).modern secretary and entrepreneurial development. Business Education journal (book of reading). 1 (3), p 29.

Ibigbami, D. (2001).designing national training and retraining programme in Business Education Journal. 3 (4), p. 12.

Federal Republic of Nigeria (1989) national policy on education Yaba Lagos: Government press.

Oguoma, D. D. (2002). Training for the world of work-a missing link. Business Education Journal. 3 (5), p.58.

Otoba, J. and G. I. Makeri Yahaya (2002).Educational needs for the Secretary in the 21 century. Business Education Journal. 3 (5), p.16.

Aminu (2006) Secretarial Education as tool for National Development. Being paper presented at national conference of Vocational and Technical Education F.C.E Zuba. 